\title{
Recovery of proliferative capability in gamma irradiated Colpoda cucullus (ciliated protist) resting cysts and its radiation hormesis
}

\author{
Ryota Saito ${ }^{1}$, Ryota Koizumi ${ }^{1}$, Tatsuya Sakai ${ }^{1}$, \\ Taiga Shimizu', Taiki Ono', Manfred Wanner', \\ Toshio Takyu ${ }^{3}$, Toshihiko Tanaka ${ }^{1}$ and \\ Yoichiro Sogame ${ }^{1}$
}

\author{
${ }^{1}$ National Institute of Technology Fukushima College, 30 Nagao Kamiarakawa \\ Taira Iwaki, Fukushima, 970-8034 Japan \\ ${ }_{2}^{2}$ Department Ecology, Brandenburg University of Technology Cottbus-Senftenberg, \\ D-03013 Cottbus, Germany \\ ${ }^{3}$ Institute of Crop Science, National Institute of Agriculture and Food Research \\ Organization, 2425 Kamimurata Hitachiomiya city, Ibaraki, 319-2293 Japan
}

| Submitted September 5, 2020| Accepted September 21, 2020 |

\begin{abstract}
Summary
The resting cyst is one of the quietest life stages (i.e. cryptobiosis) with hardly measurable or even ceased metabolic activity. However, are the resting cysts just resting? Here, to our knowledge, we report for the first time radiation hormesis in resting cysts. In the present study, we focused on the proliferative capability of excysted cells from 500-4000 Gy-gamma-irradiated Colpoda cucullus resting cysts by a bioassay method. Generally, excysted cells from irradiated cysts lose their proliferative capability. However, we observed an increased proliferative capability promoted by low doses of irradiation. Cells, which had excysted from $500-\mathrm{Gy}-$ irradiated cysts, restored their proliferation capability with a recovery period of $12 \mathrm{~h}$ and $24 \mathrm{~h}$ before excysting. Additionally, cells, which had excysted from 500-4000-Gy irradiated cysts, recovered proliferative capability by re-forming resting cysts. Here, the proliferative capability of excysted cells from 500-Gy-irradiated cysts was even higher than that of non-irradiated.
\end{abstract}

Key words: cyst, cell proliferation, hormesis, stress repair, recover

\section{Introduction}

The antagonistic processes of encystment and excystment constitute a cell cycle (E-E cycle), which is connected to the growth-division cell cycle $(\mathrm{G}-\mathrm{D}$ cycle) (Fig. 1, A; Gutiérrez et al., 2003; Verni and Rosati, 2011). Encystment, i.e. the resting cyst formation of free-living ciliates (protists) such as Colpoda cucullus, is a unique surviving strategy for protection from environmental stress. A resting

doi:10.21685/1680-0826-2020-14-3-5 
cyst is a life stage as cryptobiosis (Gutiérrez et al., 1990), with extremely decreased or cease metabolic activity in a reversible manner (Keilin, 1959; Clegg, 2001). In contrast, 'protection' in active life stages is generally related with high-energy costs.

Encystment is a reversible cell differentiation process accompanied by drastic morphological changes (Funatani et al., 2010; Verni and Rosati, 2011) in order to build cyst specific cell structures such as a cyst wall, and cease metabolic activity (Funatani et al., 2010; Sogame et al., 2014). Such resting cysts can tolerate desiccation (Taylor and Stickland, 1936), freezing (Bychenkova et al., 1969; Uspenskaya and Lozina-Lozinski, 1979), extreme temperatures (Taylor and Stickland, 1936), ultraviolet irradiation (Uspenskaya and LozinaLozinski, 1979; Matsuoka et al., 2017), acidification (Sogame et al., 2011), and gamma irradiation (Saito et al., 2020), allowing them to survive considerable environmental stress. Nevertheless, are the resting cysts really just resting with ceased metabolic activity? Recently, we said 'no', since resting cysts are able to repair cell damages caused by irradiation (Sogame et al., 2019a). The capability for excystment of irradiated cysts was recovered if there was a radiation-free period (recovery period) before excystment induction (Sogame et al., 2019a).

In this study, we focus on the effect of gamma irradiation in G-D cycle following the E-E cycle when the resting cysts were irradiated. We show that resting cysts have an active biological response for repair cell damages promoted by stress, its hormesis effect, despite the fact that their metabolic activity is hardly measurable or ceased.

\section{Material and methods}

\section{Culture}

Colpoda cucullus R2TTYS strain (Sogame et al., 2019b) was cultured in a $0.05 \%(\mathrm{w} / \mathrm{v})$ driedrice-leaves infusion supplemented with $\mathrm{Na}_{2} \mathrm{HPO}_{4}$ [0.05\% (w/v), final conc.] (culture medium) at room temperature $\left(25^{\circ} \mathrm{C}\right)$. Klebsiella pneumoniae NBRC13277 strain was provided as a food source.

\section{MicrosCopy}

Micrographs of $C$. cucullus R2TTYS vegetative cell resting cyst, and reproductive cysts (dividing cells) (Fig. 1, B) were taken by using an Axio Vert. A1 System (Carl Zeiss Microscopy Co. Ltd. Tokyo, Japan).

\section{INDUCTION OF ENCYSTMENT AND EXCYSTMENT}

Colpoda vegetative cells were encysted by replacing the culture medium with an encystment-inducing medium $(1 \mathrm{mM}$ Tris- $\mathrm{HCl} \mathrm{pH}=7.2,0.1 \mathrm{mM}$ $\mathrm{CaCl}_{2}$ ) and suspending the cells at a high cell density $\left(10,000\right.$ cells $\left.\mathrm{mL}^{-1}\right)$. The excystment of Colpoda cysts was induced by replacing the encystment-inducing medium with an excystment-inducing medium $(0.2$ $\% \mathrm{w} / \mathrm{v}$ dried-rice-leaves infusion supplemented with $\mathrm{Na}_{2} \mathrm{HPO}_{4}[0.05 \%$ (w/v), final conc. $\left.]\right)$.

\section{GAMMA IRRADIATION}

Cyst samples were irradiated with gamma rays at 500 Gy (0.5 Gy min-1), 1000 Gy (0.9), 2000 Gy (1.9), $3000 \mathrm{~Gy}$ (2.8), or $4000 \mathrm{~Gy}$ (3.7) using the irradiation machine RE2022 (Toshiba, Japan) with a cobalt 60 radiation source at the National Agriculture and Food Research Organization in Tsukuba, Japan, as described previously (Sogame et al., 2019a).

\section{SAMPLE PREPARATION, EVALUATION OF ENCYSTATION} RATES AND CELL PROLIFERATION

Vegetative cells were induced to encyst in a Petri dish as mentioned above and incubated for more than 1 week to obtain cyst samples (Fig. 2, A). The cyst samples were incubated in the laboratory at room temperature for control (non-irradiated cyst samples, Fig. 2, B), or irradiated as mentioned above (irradiated cyst samples, Fig. 2, C).

The cyst samples (Fig. 2, B, C) were induced to excyst for $9 \mathrm{~h}$ to obtain excysted cells from nonirradiated (Ex-Nir, Fig. 2, D) and irradiated (ExIr, Fig. 2E) cysts. The excysted cells (Fig. 2, D, E) were induced to re-encyst (see above) to obtain re-encysted cysts of non-irradiated (Fig. 2, F) and irradiated (Fig. 2, G) cysts. The re-encysted cysts (Fig. 2, F, G) were induced to re-excyst to obtain re-excysted cells of non-irradiated (ReEx-Nir, Fig. 2, H) and irradiated (ReEx-Ir, Fig. 2, I) cysts.

If cyst samples (Fig. 2, B, C) were given a recovery period, they were incubated for $12 \mathrm{~h}$ or $24 \mathrm{~h}$ before excystment induction (non-irradiated cysts with recovery time, Fig. 2, J; irradiated cysts with recovery time, Fig. 2, K). These cyst samples (Fig. 2, J, K) were induced to excyst to obtain excysted cells of non-irradiated cysts with recovery period (Ex-NirR, Fig. 2, L) and excysted cells of irradiated cysts with recovery period (Ex-IrR, Fig. 2, M).

The encystation rate of samples (Fig. 2, D, E) at $0,3,6,12 \mathrm{~h}$ after the onset of encystment induction 

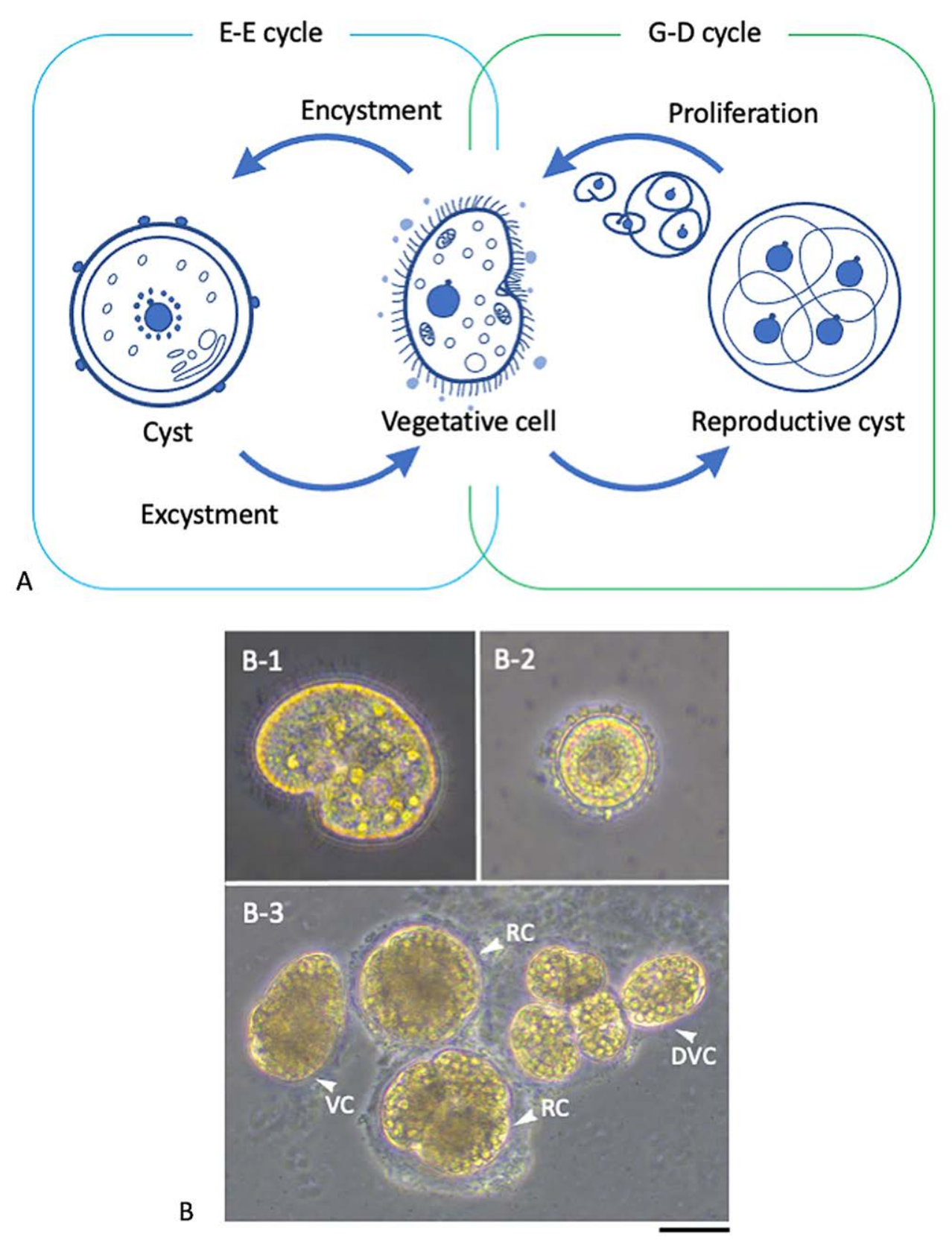

Fig. 1. Colpoda general life cycle and micrographs of C. cucullus R2TTYS. A -Schematic E-E cycle connected to the growth-division cell cycle; B - light microscopical observation of C. cucullus R2TTYS; vegetative cell (B-1), resting cyst (B-2), and reproductive cysts (B-3). Abbreviations: $\mathrm{VC}$ - vegetative cell; $\mathrm{RC}$ - reproductive cysts; DVC - daughter vegetative cell. Scale bar: $20 \mu \mathrm{m}$.

was calculated as follows: encystation rate $=$ number of encysted cells $\times$ (number of encysted and nonencysted cells) $)^{-1} \times 100$. For each analysis, more than 100 cells were counted.

We evaluated the proliferation rate of excysted cell samples (Fig. 2, D, E,H, L, I, and M). After 9 hours of excystment induction, 20 cells from each sample were suspended in $2 \mathrm{~mL}$ of fresh culture medium. The number of cells in a $100 \mu \mathrm{L}$ aliquot (5\% of the total culture volume) was counted directly under a microscope (Stemi 305; Carl Zeiss Co., Ltd., Tokyo, Japan) at set times after suspension to evaluate the proliferation rates.

The Mann-Whitney U test was used to analyze for significance of differences between samples $(\mathrm{n}=5$, Fig. 5; $\mathrm{n}=6$, Figs. 3, 4, 6, 7). 


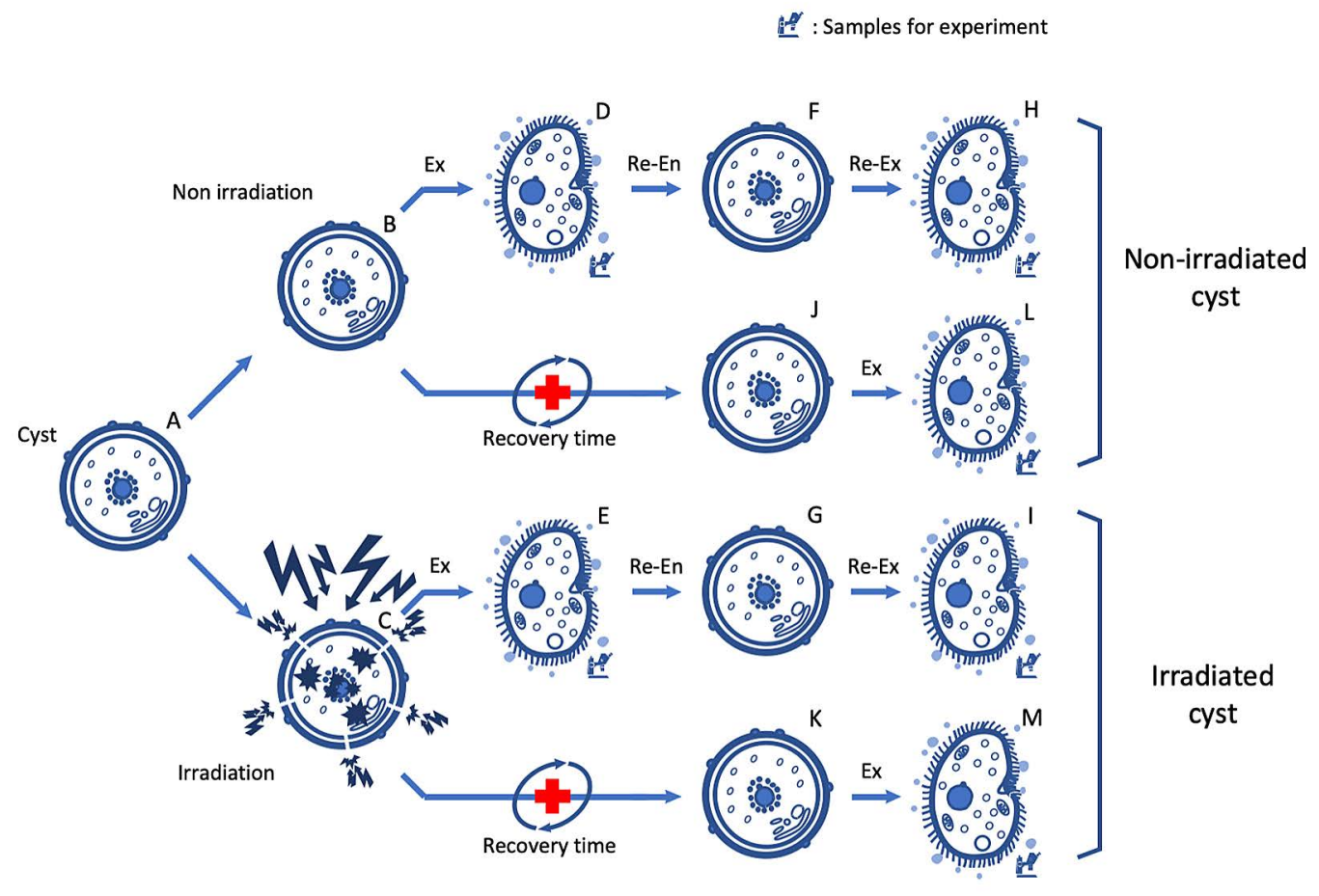

Fig. 2. Schematic of experiments / sample preparation. A - 1 week old cysts, B - non-irradiated cysts, C irradiated cysts, D - excysted cells from non-irradiated cysts (Ex-Nir), E - excysted cells from irradiated cysts (Ex-Ir), F - re-encysted cysts of non-irradiated cysts, $\mathrm{G}$ - re-encysted cysts of irradiated cysts, $\mathrm{H}$ - reexcysted cells of non-irradiated cysts (ReEx-Nir), I - re-excysted cells of irradiated cysts (ReEx-Ir) cysts, $\mathrm{J}$ - non-irradiated cysts with recovery time, $\mathrm{K}$ - irradiated cysts with recovery time, $\mathrm{L}$ - excysted cells from non-irradiated cysts with recovery period (Ex-NirR), M - excysted cells from irradiated cysts with recovery period (Ex-IrR), Ex - excystment induction, Re-En - re-encystment, Re-Ex - re-excystment.

\section{Results}

\section{Cell cycle}

The Colpoda encystment and excystment cycle (E-E cycle) connected to the growth-division cell cycle (G-D cycle) is shown in Fig. 1, A. Micrographs of the respective life stages of $C$. cucullus R2TTYS are shown in Fig. 1, B [vegetative cells (Fig. 1, B-1), resting cyst (Fig. 1, B-2), and reproduction cysts (Fig. 1, B-3)].

Cell growth assay of Ex-NIr samples and Ex-Ir SAMPLES

The proliferation of Ex-NIr samples (Fig. 2, D) and Ex-Ir samples (Fig. 2, E) is shown in Fig. 3. All cells barely proliferated during the first $36 \mathrm{~h}$, after which non-irradiated samples started to proliferate rapidly whereas the other samples did not. The cell density of non-irradiated samples at $108 \mathrm{~h}$ (Fig. 3, B) increased more than tenfold $(102.3 \pm 10.71$ cells
$100 \mu \mathrm{L}^{-1}$ ) whereas the other samples increased less than 3.5 -fold.

Re-ENCYSTMENT ASSAY OF EX-NIR SAMPLES AND EXIR SAMPLES

Ex-Nir samples (Fig. 2, D) and Ex-Ir samples (Fig. 2, E) were induced to re-encyst and the encystment was evaluated at each time point $(0,3$, 6 , and $12 \mathrm{~h}$ after the onset of encystment induction) (Fig. 4, A, B). More than $90 \%$ of the cells re-encysted $3 \mathrm{~h}$ after the induction of encystment under all irradiation conditions. The encystment of irradiated samples was significantly higher than that of nonirradiated samples $(p<0.01$ or $p<0.05$, Fig. 4 , B).

Cell growth assay of Ex-NirR samples and ExIRR SAMPLES

The non-irradiated / irradiated cysts (Fig. 2, $\mathrm{B}, \mathrm{C})$ were given a recovery period of $12 \mathrm{~h}$ or 24 $\mathrm{h}$, respectively, before excystment induction (Fig. 

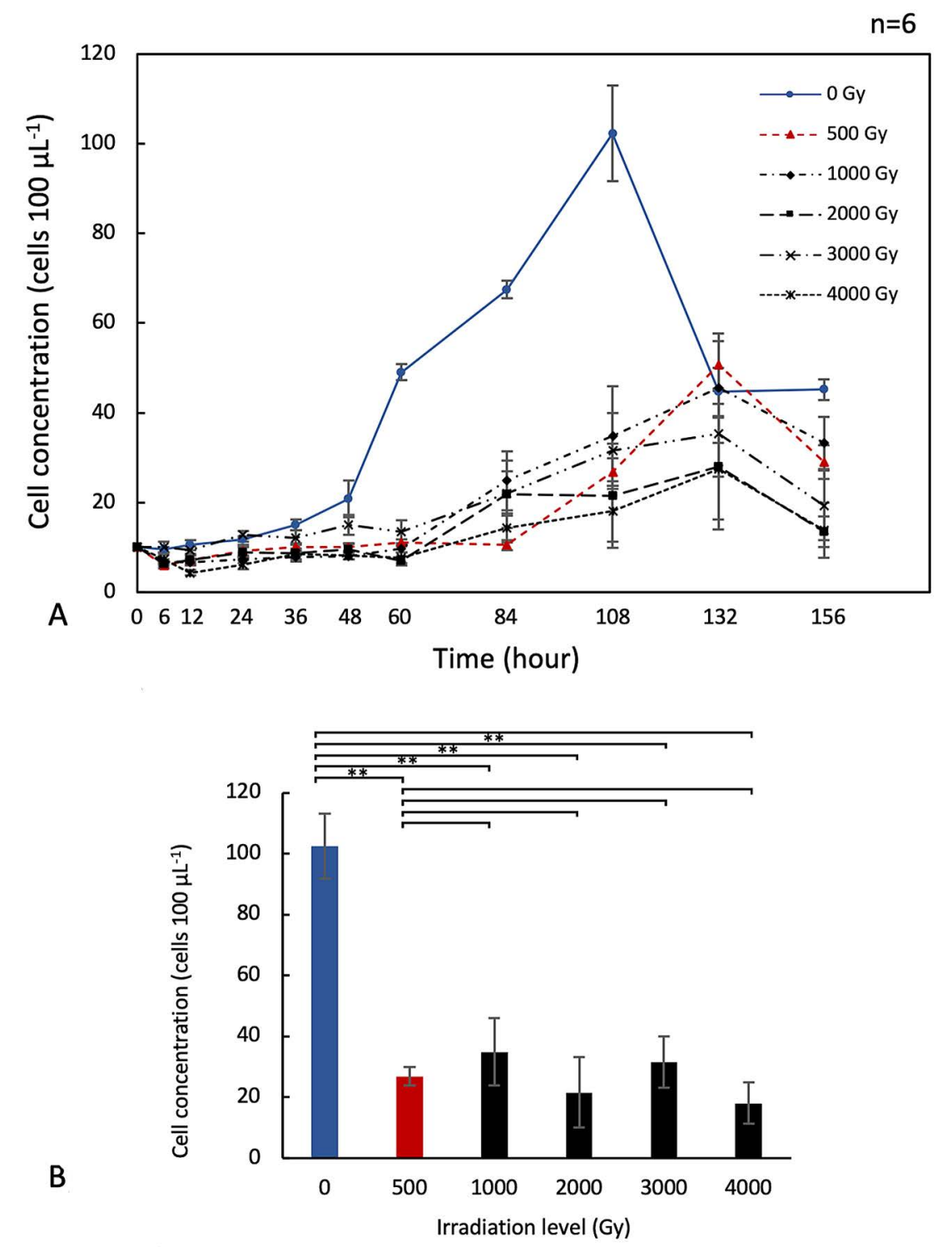

Fig. 3. Evaluation of the proliferation rate of excysted cells from non-irradiated / irradiated cysts. A Proliferation at various time points; B - proliferation $108 \mathrm{~h}$ after cell suspension. The data points or columns, and error bars represent the means and standard errors of six identical samples, respectively. Asterisks and double asterisks indicate a significant difference at $p<0.05$ and $p<0.01$, respectively.

2, J, K). The recovery period was incorporated to allow the cells to repair their cell damages due to irradiation. The samples with recovery period (Fig. 2, J, K) were induced to excyst for $9 \mathrm{~h}$ and the proliferation of Ex-NirR (Fig. 2, L) samples and Ex-IrR samples (Fig. 2, M) were evaluated. The data of Ex-NirR (Fig. 2, L) samples and Ex-IrR samples (Fig. 2, M) with a recovery period of $12 \mathrm{~h}$ and $24 \mathrm{~h}$ before excystment induction are shown in Fig. 5 and Fig. 6, respectively.

The most striking result was that irradiation with $500 \mathrm{~Gy}$ promoted proliferation (after the given recovery period). The cell density of non-irradiated and 500-Gy-irradiated samples started to increase $48-60 \mathrm{~h}$ and $60-84 \mathrm{~h}$, respectively, after suspension in a fresh culture medium. Non-irradiated samples (cells) proliferated faster than irradiated samples. However, the cell densities of 500-Gy-irradiated samples at 108 h (Fig. 5,B; 6,B) and 132 h (Fig. 5, $\mathrm{C} ; 6, \mathrm{C}$ ) were significantly higher compared to other irradiated samples $(\mathrm{p}<0.01)$ and non-irradiated samples $(\mathrm{p}<0.01$ or $\mathrm{p}<0.05)$, except for samples at $108 \mathrm{~h}$ with recovery period for $12 \mathrm{~h}$ (Fig. 5, B). The cell density of non-irradiated samples with $12 \mathrm{~h}$ 

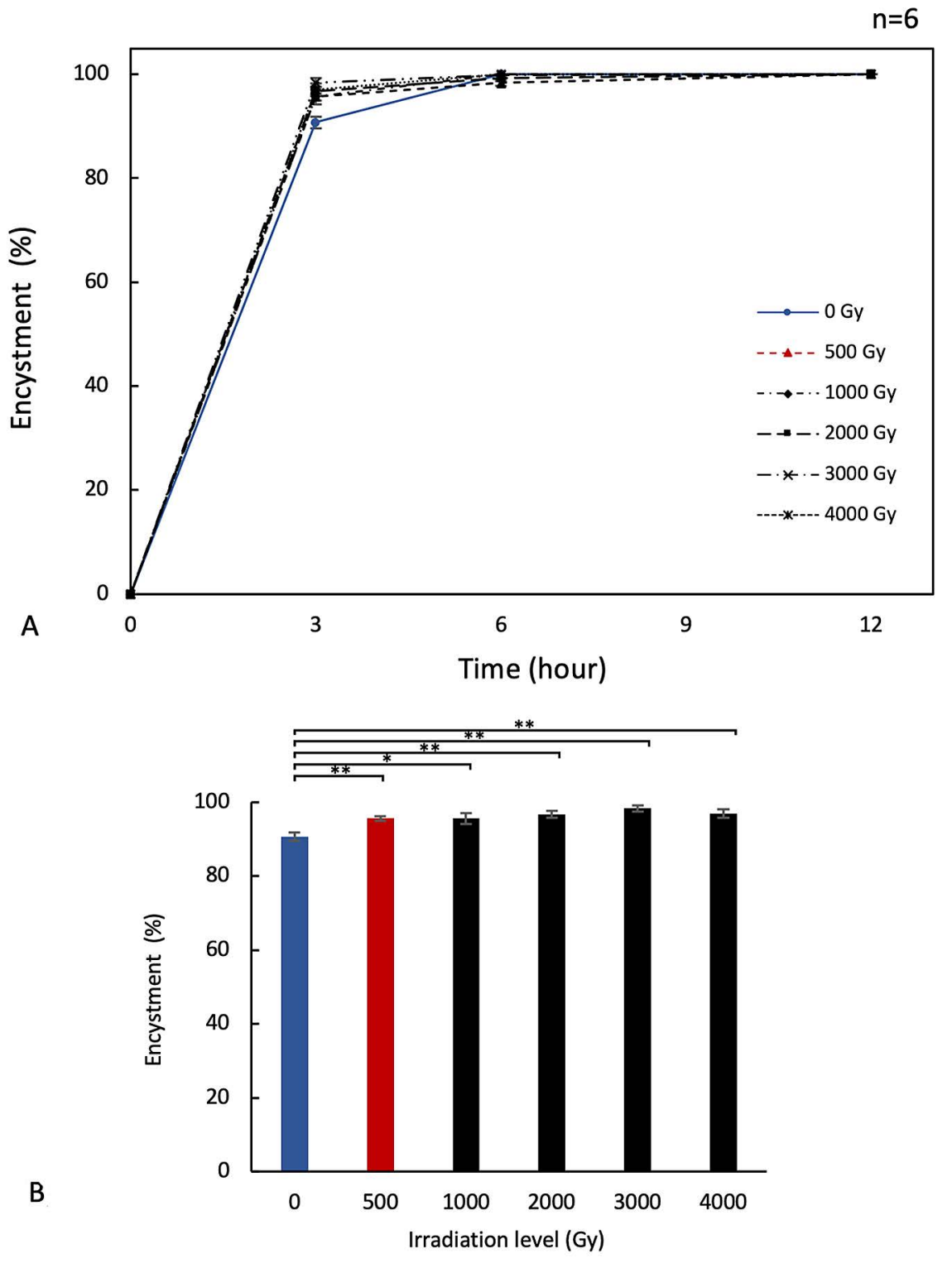

Fig. 4. Encystment assay of excysted cells from non-irradiated / irradiated cysts. A - Time-dependent encystment assay of excysted cells from non-irradiated / irradiated cysts; B - encystment of $3 \mathrm{~h}$ after onset of encystment induction. Points or columns, and error bars correspond to the means and standard errors, respectively, of six measurements. Asterisks and double asterisks indicate a significant difference at $p<0.05$ and $p<0.01$, respectively.

recovery period increased about 6 -fold $(59.0 \pm 3.96$ cells $100 \mu \mathrm{L}^{-1}$, Fig. 5, B) at $108 \mathrm{~h}$ and 8 -fold (78.6 \pm 2.64 cells $100 \mu \mathrm{L}^{-1}$, Fig. 5C) at $132 \mathrm{~h}$, whereas that of 500-Gy-irradiated samples increased 8-fold $\left(81.8 \pm 8.87\right.$ cells $100 \mu \mathrm{L}^{-1}$, Fig. 5, B) at $108 \mathrm{~h}$ and 12-fold (121.6 \pm 4.31 cells $100 \mu \mathrm{L}^{-1}$, Fig. 5, C) at 132 $\mathrm{h}$, respectively. The cell density of non-irradiated samples with $24 \mathrm{~h}$ recovery period increased about 7-fold (74.0 \pm 1.18 cells $100 \mu \mathrm{L}^{-1}$, Fig. 6, B) at 108 h or 4 -fold (42.2 \pm 3.84 cells $100 \mu \mathrm{L}^{-1}$, Fig. 6, C) at $132 \mathrm{~h}$, whereas that of $500-$ Gy-irradiated samples increased 10 -fold (105.2 \pm 6.76 cells $100 \mu \mathrm{L}^{-1}$, Fig. 6 , B) at $108 \mathrm{~h}$ or 10 -fold $\left(96.2 \pm 8.77\right.$ cells $100 \mu \mathrm{L}^{-1}$, Fig. $6, \mathrm{C})$ at $132 \mathrm{~h}$, respectively. Little proliferation of the other cell samples (less than 5-fold) was observed at $108 \mathrm{~h}$ and $132 \mathrm{~h}$.

Cell growth assay of ReEx-NIr samples and ReEX-IR SAMPLES

The re-encysted cells of non-irradiated / irradiated cysts (Fig. 2F, G) were induced to re-excyst and 

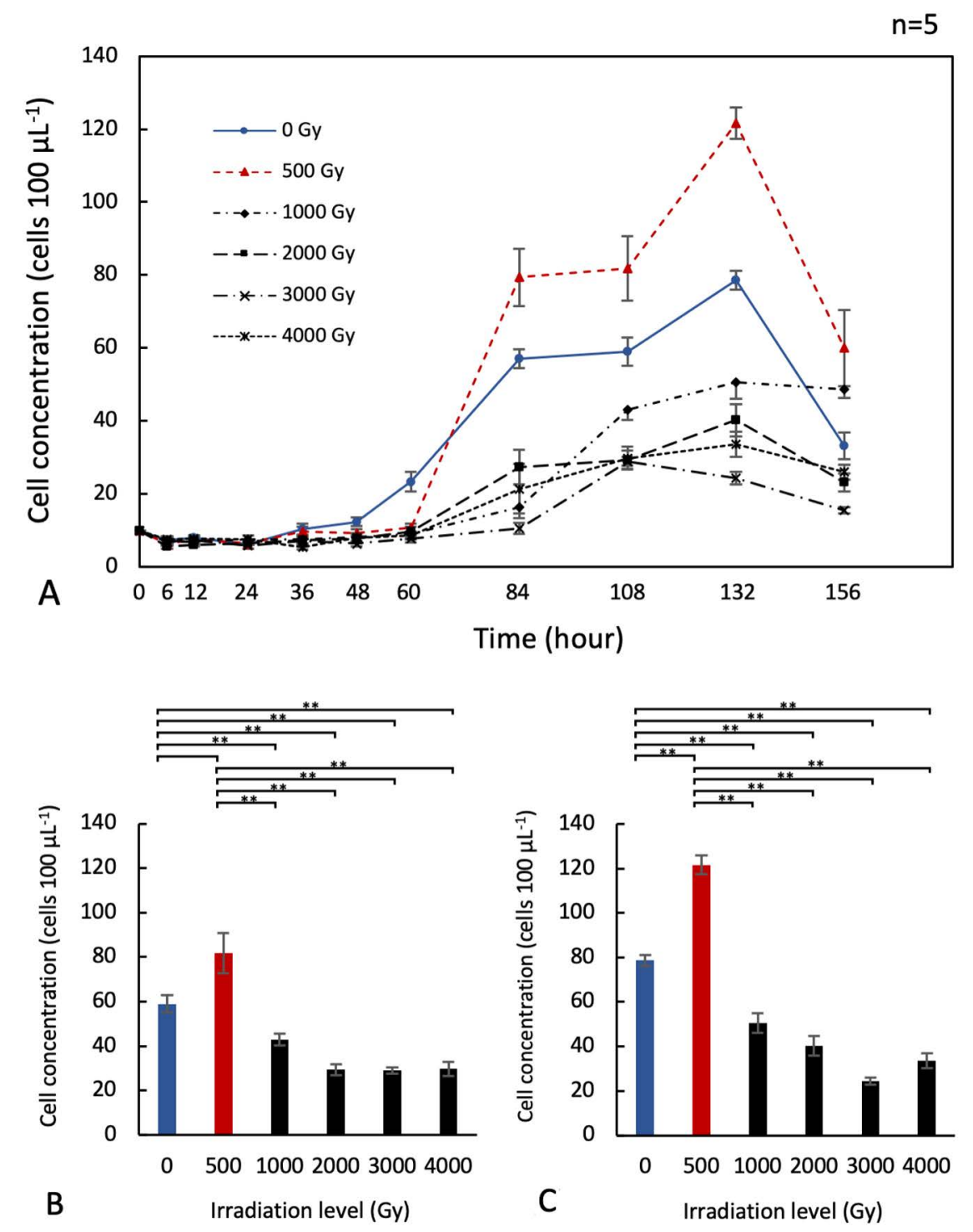

Fig. 5. Evaluation of the proliferation rates of excysted cells from non-irradiated / irradiated (500-4000 Gy) cysts with a recovery period for $12 \mathrm{~h}$ at various time points. A - Proliferation rates at various time points; B - proliferation rates $108 \mathrm{~h}$, and $\mathrm{C}-132 \mathrm{~h}$ after cell suspension. The data points or columns, and error bars represent the means and standard errors of five identical samples, respectively. Asterisks and double asterisks indicate a significant difference at $p<0.05$ and $p<0.01$, respectively.

the proliferation of ReEx-Nir samples and ReEx-Ir samples (Fig. 2, H, I) was evaluated (Fig. 7, A, B). There was no change in cell density during the first $12 \mathrm{~h}$ after suspension in a fresh culture medium. The proliferation of all samples increased and was more than 10 -fold at $60 \mathrm{~h}$ after suspension, as shown by the columns (Fig. 7B). The increase of the 500-Gyirradiated samples tended to be (non-significantly) higher than that of the non-irradiated / irradiated samples.

\section{Discussion}

Our study showed that 500 Gy irradiation to resting cysts caused a favorable effect in G-D cycle if the irradiated resting cysts were given a recovery period. We interpret our data as radiation hormesis considering cell recovery in resting cysts.

Hormesis implies a favorable biological response to mild damage and stressors, as suggested by Southam and Ehrich (1943), according to Kudryasheva 

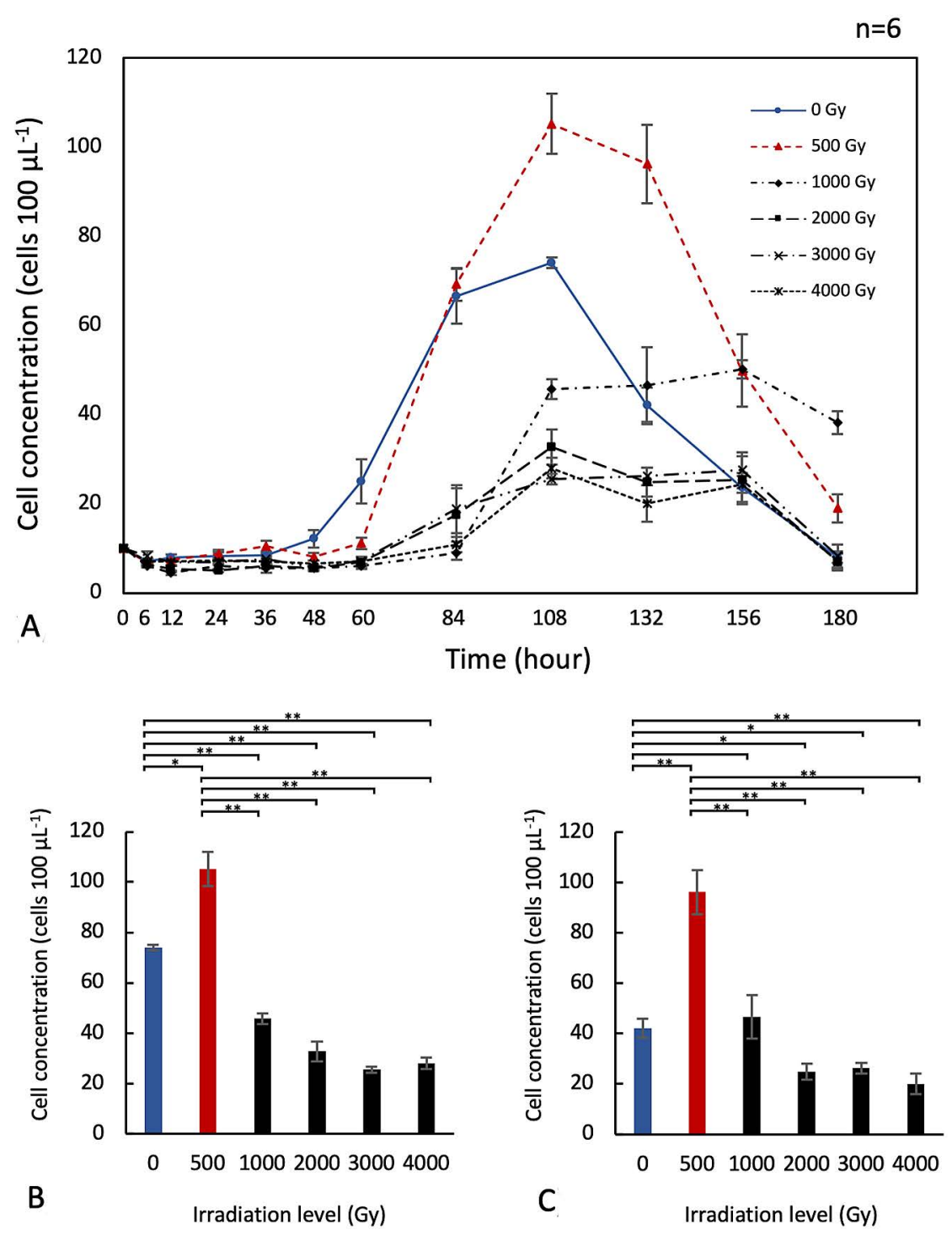

Fig. 6. Evaluation of the proliferation rates of excysted cells from non-irradiated / irradiated (500-4000 Gy) cysts with a recovery period for $24 \mathrm{~h}$ at various time points. A - Proliferation rates at various time points; B - proliferation rates $108 \mathrm{~h}$, and $\mathrm{C}-132 \mathrm{~h}$ after cell suspension. The data points or columns, and error bars represent the means and standard errors of six identical samples, respectively. Asterisks and double asterisks indicate a significant difference at $p<0.05$ and $p<0.01$, respectively.

and Kovel (2019). In the case of gamma irradiation, low doses of irradiation at $<200 \mathrm{mSv}$ (approximately $160 \mathrm{mGy}$ ) induce beneficial effects as radiation hormesis (Shimbamoto and Nakamura, 2018), which promote growth and development (Luckey, 1982). In the ciliate Paramecium tetraurelia, the growth rate was reported to be suppressed by shielding background irradiation (Planel et al., 1976), suggesting that low-dose irradiation (background irradiation) promoted cell proliferation, although this was not suggested as radiation hormesis. Si- milar effects of background irradiation on cell proliferation were observed in the cyanobacterium Synechococcus lividas (Conter et al., 1983; Planel et al., 1987) and in the mouse L5185 cell line (Takizawa et al., 1992; Kawanishi et al., 2012).

To our knowledge, this study is the first report about hormesis in ciliate resting cysts. Interestingly, irradiating vegetative cells with 500 Gy caused irreparable damage (Saito et al., 2020) but similar irradiation to resting cysts was converted into a favorable effect if the resting cysts were given a 

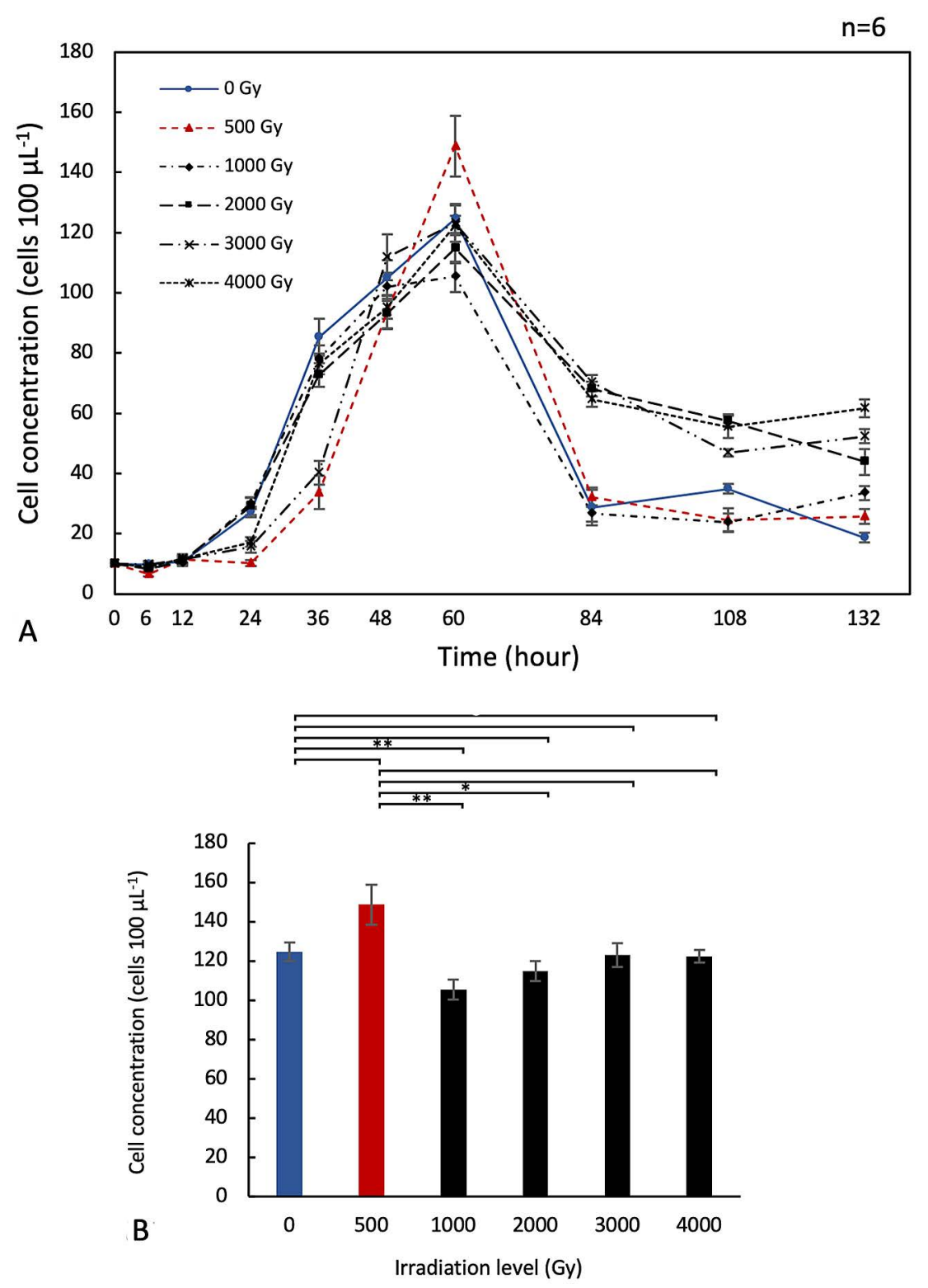

Fig. 7. Evaluation of the proliferation rates of re-excysted cells of non-irradiated / irradiated cysts at various time points. A - Proliferation rates at various time points; B - proliferation rates $60 \mathrm{~h}$ after cell suspension. The data points or columns, and error bars represent the means and standard errors of six identical samples, respectively. Asterisks and double asterisks indicate a significant difference at $p<0.05$ and $p<0.01$, respectively.

recovery period. These results imply that resting cysts have an active biological response repairing cell damages caused by stress, despite the fact that their metabolic activity should be inactivated or hardly measurable.

The most important and interesting point in the present study is that the proliferation capability of 500-Gy-irradiated cysts was higher than that of nonirradiated cysts if they were given a recovery period of $12 \mathrm{~h}$ or $24 \mathrm{~h}$ before excystment induction, even though the other irradiated cysts could barely pro- liferate. Similarly, proliferation capability tended to be higher by $500 \mathrm{~Gy}$ irradiation after re-encystation. Although 500-Gy irradiation showed radiation hormesis, it is too high to support radiation hormesis according to a standard value $(<200 \mathrm{mSv})$ described in Shibamoto and Nakamura (2018). The radiation level for cysts supporting hormesis is likely high, but for vegetative cells it can be expected low, such as the level of environmental radioactivity described in Planel et al. (1976), Croute et al. (1980), and Tixador et al. (1981) in P. tetraurelia. In fact, most 
cysts could tolerate 500 Gy of irradiation, although it caused irreparable damage for vegetative cells (Saito et al., 2020).

Our previous study (Saito et al., 2020) showed that most (>97\%) Colpoda cysts irradiated at 5004000 Gy could revert to vegetative cells. However, the present study demonstrated that the excysted cells could not proliferate. Then, why does $C$. $c u$ cullus acquire tolerance against gamma rays? It seems biologically unnecessary for them because they inhabit mainly puddles, which are normally not exposed to radiation. However, it seems advantageous to develop tolerance against desiccation, which occurs frequently in temporal water environments such as puddles. Exposure not only to gamma rays (Azzam et al., 2012) but also to desiccation (França et al., 2007) produces reactive oxygen species (ROS) damaging cells of protist (Slaveykova et al., 2016). Thus, Colpoda probably have evolved tolerance to gamma rays because of tolerating ROS stress caused by desiccation rather than experiencing the direct effects of gamma rays. Even if the resting cyst formation is a strategy for adapting to an unfavorable environment including desiccation, it should be important that the cysts have both the capability to excyst and the ability to proliferate after tolerating environmental stress. However, the present study and our previous research showed that the irradiated cysts could excyst after irradiation, whereas they could barely proliferate. Why do irradiated cysts excyst even though they will not proliferate? The cysts might excyst to migrate to a more suitable environment, despite the energy penalty and their inability to proliferate. It would be advantageous for Colpoda to act as $r$-strategists (Lüftenegger et al., 1985) as the ciliate can rapidly form highdensity populations, given that each dividing cell produces four copies (Petz et al., 1985). Each copy can subsequently become a resting cyst to survive in unfavorable environments and repair cell damages. Moreover, re-encystation of the excysted cells from irradiated cysts was faster than that of non-irradiated cysts to repair the damage as soon as possible in resting cysts. After the re-encystation, the cells completely recovered their capability to proliferate.

In this study, we showed a radiation hormesis in $C$. cucullus resting cysts. However, at the present status it is too complicated to analyze the respective processes at a molecular level. Perhaps a promising approach would be to look for deoxidation enzymes and DNA repair factors such as RAD51 (Campbell and Romero, 1998), which is activated and repair cell damage caused by irradiation. Additionally, signaling pathways for the process are probably promoted by mild stress. The tolerance and hormesis is beneficial for $r$-strategists such as Colpoda to promote fast reproduction and increase population density after excystment in a new stable environment.

The free-living ciliate has two phases in its life cycle, the E-E cycle and G-D cycle. The resting cysts formation is a most typical example of cryptobiosis - a peculiar life condition, which is most close to death. However, our findings considering repair processes in resting cysts will open a new insight of cryptobiosis. It is not only just resting or tolerating but has probably also an active phase to repair the damages induced by environmental stress.

\section{Acknowledgements}

We would like to express our deep gratitude to Dr. T. Furusawa (National Institute of Agriculture and Food Research Organization) for his suggestion for this work.

This research was financially supported by JSPS KAKENHI Grant Numbers JP 16K18827, JP 19K1693, Sasagawa Scientific Research Grant (\#29808), and Narishige Zoological Science Award.

\section{References}

Azzam E.I., Jay-Gerin J. and Pain D.P. 2012. Ionizing radiation-induced metabolic oxidative stress and prolonged cell injury. Cancer Lett. 327, 48-60.

Bychenkova V.N., Lozina-Lozinsky L.K. and Namalov T. 1969. Microscopic observations of the processes of freezing and thawing in Colpoda maupasi. Zool. ZH. 48, 1772-1779.

Campbell C. and Romero D.P. 1998. Identification and characterization of the RAD51 gene from the ciliate Tetrahymena thermophila. Nucleic Acids Res. 26, 3165-3172.

Clegg S.J. 2001. Cryptobiosis: a peculiar state of biological organization. Comp. Biochem. Physiol. B. $128,613-624$.

Conter A., Dupouy D. and Planel H. 1983. Demonstration of a biological effect of natural ionizing radiations. Int. J. Radiat. Biol. Relat. Stud. Phys. Chem. Med. 43, 421-432. 
Croute F., Dupouy D., Charley J.P., Soleilhavoup J.P. and Planel H. 1980. Effects of autogamy in Paramecium tetraurelia on catalase activity and on radiosensitivity to natural ionizing radiations. J. Protozool. 27, 132-135.

França M.B., Panek A.D. and Eleutherio E.C. 2007. Oxidative stress and its effects during dehydration. Comp. Biochem. Physiol. A. 146, 621-631.

Funatani R., Kida A., Watoh T. and Matsuoka T. 2010. Morphological events during resting cyst formation in the ciliate Colpoda cucullus. Protistology. 6, 204-217.

Gutiérrez J.C., Martin-GonzalezA. and Matsusaka T. 1990. Towards a generalized model of encystment (cryptobiosis) in ciliates: a review and a hypothesis. Biosystems. 24, 17-24.

Gutiérrez J.C., Diaz S., Ortega R. and MartinGonzales A. 2003. Ciliate resting cysts walls: A comparative review. Recent Research Developments in Microbiology. 7, 361-379.

Kawanishi M., Okuyama K., Shiraishi K., Matsuda Y., Taniguchi R., Shiomi N., Yonezawa M. and Yagi T. 2012. Growth retardation of Paramecium and mouse cells by shielding them from background radiation. J. Radiat. Res. 53, 404-410.

Keilin D. 1959. The problem of anabiosis or latent life: history and current concept. Proc. Roy. Soc. Lond. B. 150, 149-191.

Kudryasheva S.N. and Kovel S.E. 2019. Monitoring of low-intensity exposures via luminescent bioassays of different complexity: cells, enzyme reactions, and fluorescent proteins. Int. J. Mol. Sci. 20, 4451 .

Luckey T.D. 1982. Hormesis with ionizing radiation. Nucl. Sci. Eng. 82, 365-366.

Lüftenegger G., Foissner W. and Adam H. 1985. R- and K-selection in soil ciliates: a field and experimental approach. Oecologia. 66, 574-579.

Matsuoka K., Funadani R. and Matsuoka T. 2017. Tolerance of Colpoda cucullus resting cysts to ultraviolet irradiation. J. Protozool. Res. 27, 1-7.

Petz W., Foissner W. and Adam H. 1985. Culture, food selection and growth rate in the mycophagous ciliate Grossglockneria acuta Foissner, 1980: first evidence of autochthonous soil ciliate. Soil Biol. Biochem.17, 871-875.

Planel H., Soleilhavoup J.P., Tixador R., Croute F. and Richoilley G. 1976. Demonstration of a stimulating effect of natural ionizing radiation and of very low radiation doses on cell multiplication. International Atomic Energy Agency, Vienna (Aust- ria); World Health Organization, Geneva (Switzerland); Proceedings series; v. 1, 127-139.

Planel H., Soleilhavoup J.P., Tixador R., Richoilley G., Conter A., Croute F., Caratero C. and Gaubin Y. 1987. Influence on cell proliferation of background radiation or exposure to very low, chronic gamma radiation. Health Phys. 52, 571578.

Saito R., Koizumi R., Sakai T., Shimizu T., Ono T. and Sogame Y. 2020. Gamma radiation tolerance and protein carbonylation caused by irradiation of resting cysts in the free-living single cell protist Colpoda cucullus. Acta Protozool. 59, 67-75.

Shibamoto Y. and Nakamura H. 2018. Overview of Biological, Epidemiological, and Clinical Evidence of Radiation Hormesis. Int. J. Mol. Sci. 19, 2387.

Slaveykova V., Sonntag B. and Gutiérrez J.C. 2016. Stress and Protists: No life without stress. Europ. J. Protistol. 55, 39-49.

Sogame Y., Kida A. and Matsuoka T. 2011. Possible involvement of endocyst in tolerance of the resting cyst of Colpoda cucullus against $\mathrm{HCl}$. African J. Microbiol. Res. 5, 4316-4320.

Sogame Y., Kojima K., Takeshita T., Kinoshita E. and Matsuoka T. 2014. Identification of differentially expressed water-insoluble proteins in the encystment process of Colpoda cucullus by two-dimensional electrophoresis and LC-MS/MS analysis. J. Eukaryot. Microbiol. 61, 51-60.

Sogame Y., Saito R., Koizumi R., Shimizu T. and Ono T. 2019a. Evidence of stress recovery in free-living ciliate Colpoda cucullus: the repair capability of resting cysts to damage caused by gamma irradiation. Acta Protozool. 58, 25-29.

Sogame Y., Saito R., Sakai T., Shimizu T., Ono T., Koizumi R. and Mizumachi K. 2019b. Lepidosomes acquire fluorescence after encystation: Including additional notes of morphological events during encystation and reconsideration of the morphological features in the ciliate Colpoda cucullus. J. Protozool. Res. 29, 53-63.

Southam C.M. and Ehrlich J. 1943. Effects of extracts of western red-cedar heartwood on certain wood-decaying fungi in culture. Phytopathology. 33, 517-524.

Takizawa Y., Yamashita J., Wakizaka A. and Tanooka H. 1992. Background radiation can stimulate the proliferation of mouse-L-5178Y cells. Proceedings of International Conference on Radiation Effects and Protection, pp. 234-236. 
Taylor C.V. and Strickland A.G.R. 1936. Effects of high vacua and extreme temparetures on cysts of Colpoda cucullus. Physiol. Zool. 9, 15-26.

Tixador R., Richoilley G., Monrozies E., Planel H. and Tap G. 1981. Effects of very low doses of ionizing radiation on the clonal life-span in Paramecium tetraurelia. Int. J. Radiat. Biol. Relat. Stud. Phys. Chem. Med. 39, 47-54.
Uspenskaya Z.I. and Lozina-Lozinsky L.K. 1979. Antigen rearrangements in Colpoda maupasi cells after freezing at $-196^{\circ} \mathrm{C}$, and after shortwave ultraviolet irradiation. Cryobiology. 16, 542-549.

Verni F. and Rosati G. 2011. Resting cysts: a survival strategy in protozoa Ciliophora. Italian J. Zool. 78, 134-145.

Address for correspondence: Yoichiro Sogame, National Institute of Technology Fukushima College, 30 Nagao Kamiarakawa Taira Iwaki, Fukushima, 970-8034 Japan; e-mail: sogame@fukushima-nct.ac.jp; gamegamesogamail@gmail.com 